\title{
A qRT-PCR assay for the expression of all Mal $d 1$ isoallergen genes
}

\author{
Giulia Pagliarani ${ }^{1,{ }^{*}+}$, Roberta Paris ${ }^{2,4 \dagger}$, Paul Arens ${ }^{1}$, Stefano Tartarini ${ }^{2}$, Giampaolo Ricci ${ }^{3}$, Marinus JM Smulders ${ }^{1}$ \\ and W Eric van de Weg ${ }^{1}$
}

\begin{abstract}
Background: A considerable number of individuals suffer from oral allergy syndrome (OAS) to apple, resulting in the avoidance of apple consumption. Apple cultivars differ greatly in their allergenic properties, but knowledge of the causes for such differences is incomplete. Mal d 1 is considered the major apple allergen. For Mal d 1, a wide range of isoallergens and variants exist, and they are encoded by a large gene family. To identify the specific proteins/genes that are potentially involved in the allergy, we developed a PCR assay to monitor the expression of each individual Mal 11 gene. Gene-specific primer pairs were designed for the exploitation of sequence differences among Mal $d 1$ genes. The specificity of these primers was validated using both in silico and in vitro techniques. Subsequently, this assay was applied to the peel and flesh of fruits from the two cultivars 'Florina' and 'Gala'.

Results: We successfully developed gene-specific primer pairs for each of the $31 \mathrm{Mal} d 1$ genes and incorporated them into a qRT-PCR assay. The results from the application of the assay showed that 11 genes were not expressed in fruit. In addition, differential expression was observed among the Mal $d 1$ genes that were expressed in the fruit. Moreover, the expression levels were tissue and cultivar dependent.

Conclusion: The assay developed in this study facilitated the first characterisation of the expression levels of all known Mal $d 1$ genes in a gene-specific manner. Using this assay on different fruit tissues and cultivars, we obtained knowledge concerning gene relevance in allergenicity. This study provides new perspectives for research on both plant breeding and immunotherapy.
\end{abstract}

Keywords: Apple allergy, OAS, Mal d 1, Bet v 1, PR-10, gene family, qRT-PCR

\section{Background}

Apple allergy is an issue for a growing number of European citizens. As one of the most prevalent food allergies, apples rank fourth out of 24 foods examined in an extensive Pan-European survey and first among Rosaceae fruits [1]. Thus, although the apple is generally a healthy component in the human diet, an increasing number of individuals cannot eat this fruit. The allergenic properties of apple cultivars differ greatly [2,3], but knowledge of the genetic basis for low and high allergenicity remains incomplete.

\footnotetext{
* Correspondence: giulia.pagliarani2@unibo.it

${ }^{\dagger}$ Equal contributors

'Wageningen UR Plant Breeding, Plant Research International, Droevendaalsesteeg 1, Wageningen, PB 6708, The Netherlands ${ }^{2}$ Department of Fruit Tree and Woody Plant Sciences, University of Bologna, Viale Fanin 46, Bologna 40127, Italy

Full list of author information is available at the end of the article
}

Of the 4 classes of allergens currently identified in apple, Mal d 1 is thought to be the major allergen in Central and Northern Europe $[4,5]$. At the genetic level, Mal $d 1$ is a complex gene family composed of 31 different loci, each of which codes for a different isoallergen [6]. Moreover, for each isoallergen gene, there are a series of slightly different alleles that might encode for isoallergen variants, which increases the variability in Mal d 1 proteins [6-8]. Accumulating evidence has shown that isoallergens might differ greatly in their allergenic properties, but it is still unclear which of these proteins are more involved in allergy. Several approaches have been used to quantify Mal $\mathrm{d} 1$ content or gene expression; however, none of these studies covered the full set of Mal d 1 isoallergens or Mal d 1 genes. Mal d 1, similarly to Bet $\mathrm{v} 1$, is unstable to pepsin digestion, and IgE reactivity to Mal d 1 proteins is absent following the heat treatment of fruits [9]. The sensibility of Mal d 1 to

\section{Biomed Central}


high temperature and proteases hinders its proteomic analysis. Moreover, the food matrix and contaminants might affect the protein extraction. Until now, proteomics have been primarily used to quantify the total amounts of Mal d 1 content in apple fruit, without distinguishing isoallergens or variants or making distinctions within an incomplete pool of isoallergens [10-14]. Currently, there are only a few recombinant allergens derived from fruits and vegetables that are commercially available for immunological detection [15], with variable antibody specificities [16].

PCR-based expression studies are not subject to these limitations, and in particular, quantitative Real-Time PCR (qRT-PCR) is a fast, highly sensitive and reproducible technique to study gene expression. Previous studies of some Mal $d 1$ genes revealed the tissue- and cultivar-specific expression of Mal d 1 genes [17-19], and differential effects of environmental conditions $[20,21]$ on the transcription of these genes have been reported. However, these studies have not covered the entire gene family, nor have they sufficiently demonstrated the gene specificity of the PCR primer pairs used.

Thus, there is a need to characterise the role of each individual isoallergen to understand the apple allergy mechanism. Therefore, the aim of this study was to examine the expression of these genes by implementing the qRT-PCR approach. A comprehensive, robust, sensitive and affordable assay for studying the expression of all 31 known Mal d 1 genes individually was developed. We successfully used this assay to generate the complete expression profile of all $\mathrm{Mal} d \mathrm{I}$ isoallergen genes in the fruits of two cultivars.

\section{Results}

\section{Alignment of Mal d 1 genes}

A total of $380 \mathrm{Mal} d 1 \mathrm{DNA}$ and EST sequences were retrieved from the literature and databases (Additional file 1) covering all 31 known Mal $d 1$ genes described in [6]. Many sequences obtained from different apple cultivars were already annotated as Mal $d 1$ alleles. For the others, according to the level of similarity, it was possible to identify new alleles of known genes. Subsequent to alignment, the level of similarity among the coding sequences (cds) of different genes ranged from $53.1 \%$ to $97.7 \%$ and from $95 \%$ to $99.8 \%$ for the different alleles within a gene. At the protein level, the sequence identity between isoallergens ranged from 37\% (Mal d 1.08 and Mal d $1.11 \mathrm{~A}, 102 \mathrm{AA}$ substitutions) to $96 \%$ (Mal d 1.06A and Mal d 1.06D, 7 AA substitutions). The alignment of the 31 coding sequences retrieved from the 'Golden Delicious' whole genome sequence (Additional file 2) was used to generate a phenetic tree (Figure 1). This tree showed 5 clades, 4 of which have been previously described and characterised as subfamilies I-IV [7] and one clade,

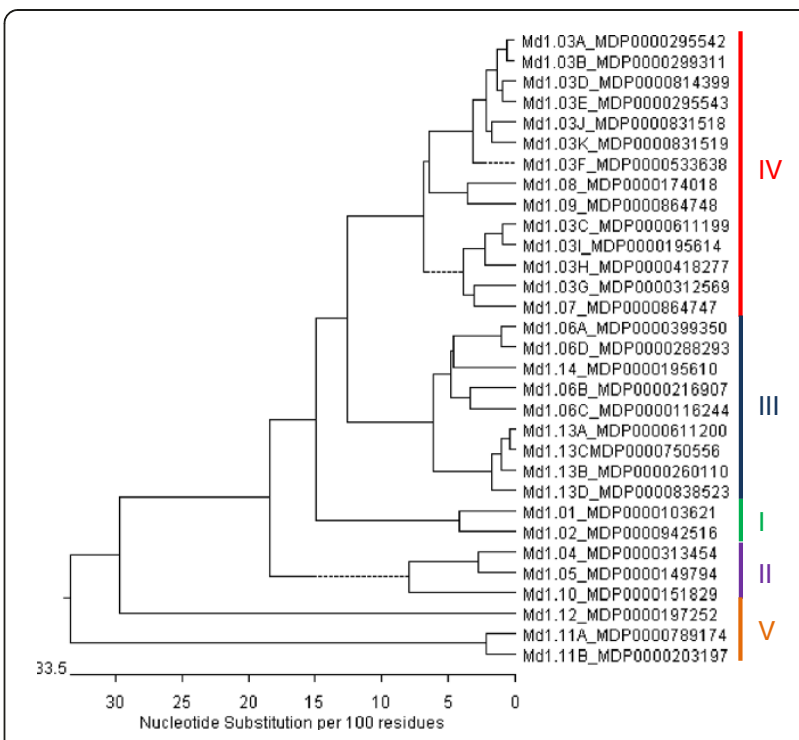

Figure $1 \mathrm{Mal} \boldsymbol{d} 1$ phenetic tree. Neighbour-joining tree based on the coding sequence of the $31 \mathrm{Mal} d 1$ isoallergen genes retrieved from the 'Golden Delicious' genome sequence (Additional file 2). The sequences are presented using the names of the related genes and the accession numbers obtained from Apple GBrowse - Malus x domestica $\vee 1.0$ [22]. The Roman numerals (I-V) and colored lines identify the subfamilies.

subfamily $\mathrm{V}$, that has been classified for the first time in the present study. The three genes in subfamily $\mathrm{V}$ (Mal $d 1.11$, Mal $d 1.11 B$ and Mal $d 1.12$ ) are the most distant within the Mal $d 1$ family.

\section{Primer design}

The development of this assay began with the design of specific primer pairs. The alignment of the $31 \mathrm{Mal} d 1$ sequences from 'Golden Delicious' (Figure 2A) highlights SNPs specific for only one gene. The robustness of these SNPs across alleles of the same gene was examined among the other allelic sequences in the alignment, using the 'Golden Delicious' sequences as a framework. An average of four gene-differentiating SNPs per sequence was detected and only these SNPs were exploited for primer design. For example, the reverse primer for Mal $d$ 1.02 is located in a region in which a SNP differentiates the Mal $d 1.02$ gene from all other genes (Figure 2A). The alignment of all allelic sequences for Mal d 1.02 (Figure 2B) shows that no additional allele-differentiating SNPs were present in this region; thus, this region was an excellent candidate for primer development. Figure $2 \mathrm{~B}$ shows an example of the reverse primer for Mal $d$ 1.01. In addition to the gene-differentiating SNP (SNP nr. 2) targeted for primer design, this primer contained one alleledifferentiating SNP (SNP nr. 6) at the 5' end. In general, regions containing only gene-differentiating SNPs were preferred for primer design; however, these regions were not always available. Thus, 12 of the 31 primer pairs 
A
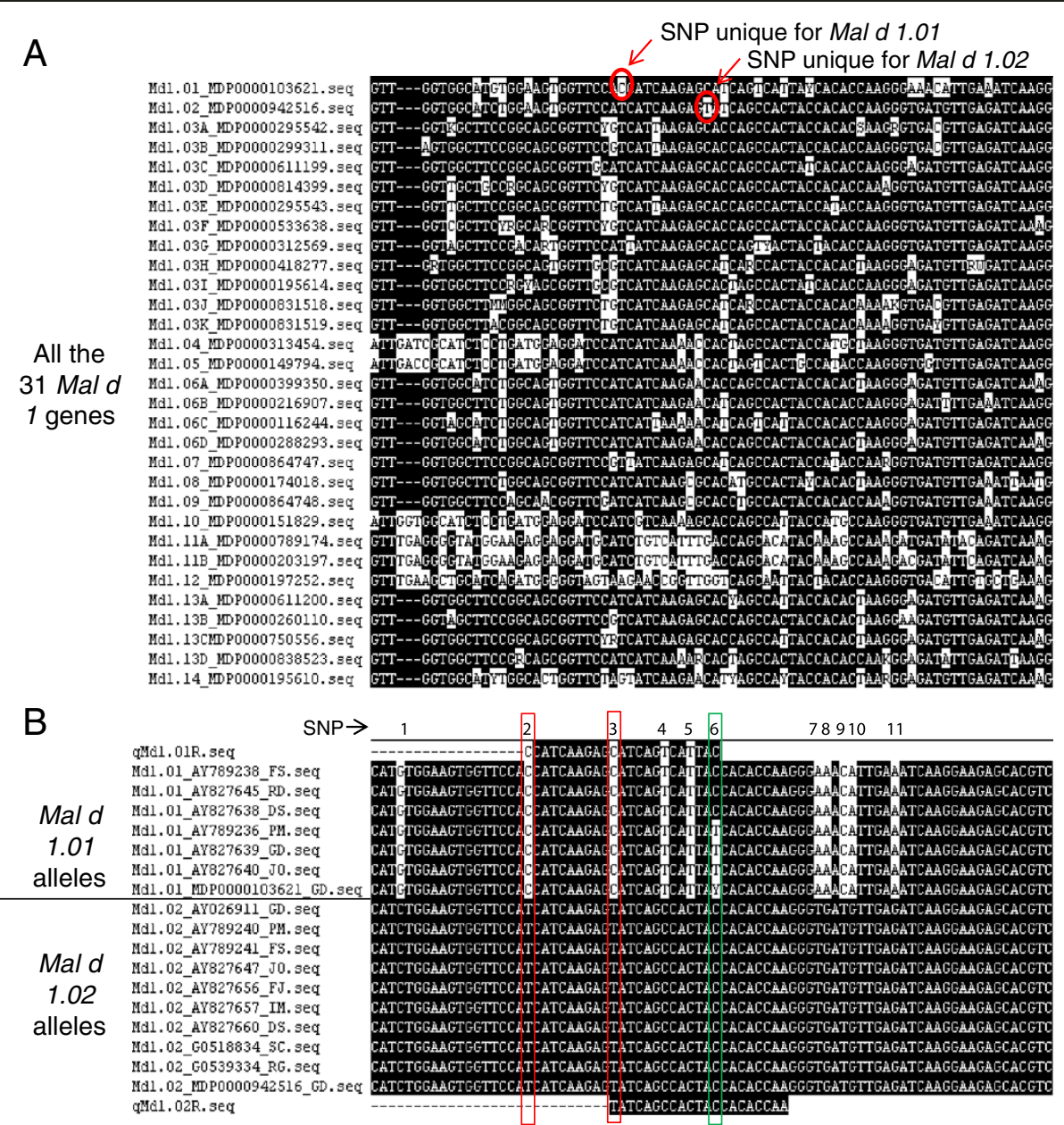

Figure 2 Primers design strategy. A) Part of the coding sequence alignment of the $31 \mathrm{Mal} d 1$ isoallergen genes was retrieved from the 'Golden Delicious' genome sequence (Additional file 2). The sequences were named according to their related Mal $d$ genes and the accession numbers retrieved from the Apple GBrowse - Malus x domestica v1.0 [22]. The white marked nucleotides highlight the mismatched residues in the consensus sequence. The SNPs specific for the loci Mal d 1.01 and -1.02 are indicated with red circles. B) Part of the alignment on all allelic gDNA sequences for Mal d 1.01 and -1.02 was obtained from the literature [8]. The sequences of the two reverse primers for Mal d 1.01 and -1.02 are also included in the alignment. The sequences were named according to their related Mal $d 1$ genes, ID numbers from the database and genotypic origins: FS: Fiesta; RD: Red Delicious; DS: Discovery; PM: Prima; GD: Golden Delicious; JO: Jonagold; FJ: Fuji; IM: Ingrid Marie; SC: Suncrisp; RG: Royal Gala. The SNP positions are indicated with successive numbers from 1 to 11. The red boxes indicate the two locusdifferentiating SNPs exploited for primer design; the green box highlights an allele-differentiating SNP.

contained allele-differentiating SNPs (Table 1). To ensure that these SNPs would not affect the PCR amplification, the allele-differentiating SNPs were accepted only if positioned at the 5 ' end of only one of the two primers. The procedure for the primer selection was performed for each of the 31 Mal 1 genes (Table 1).

\section{Primer validation and qRT-PCR optimisation}

The gene-specificity of the designed primer pairs was validated in four ways. Firstly, an in silico validation through blasting the primer sequences to known reference sequences ensured that these primers perfectly matched only with sequences corresponding to the target genes (data not shown). Only the primers that generated perfect matches were assessed in the second validation step performed through end-point PCR on genomic DNA; only the primer pairs that produced a single clear band were maintained. Thirdly, the direct sequencing of the Mal $d 1$ amplicons obtained from 10 apple cultivars was performed to ensure that only the specific target sequences were amplified (Additional file 3). Amplicons generated from gDNA were sequenced because of the higher level of complexity of gDNA compared to cDNA and this allowed to guarantee the primers specificity for all the Mal $d 1$ members, independently from their expression. Only the primers that had a unique sequence corresponding to the target gene were assessed in the last step of validation. In some cases, this specificity was 
Table 1 Mal $d$ 1specific primer pairs for qRT-PCR analysis

\begin{tabular}{|c|c|c|c|c|c|c|c|c|c|c|c|}
\hline Gene & Primer name & Sequence $5^{\prime}-3^{\prime}$ & $\begin{array}{l}\text { SNP } \\
\text { cons }^{a}\end{array}$ & $\begin{array}{l}\text { SNP } \\
\text { gene }^{b}\end{array}$ & $\begin{array}{l}\text { SNP } \\
\text { allele }^{c}\end{array}$ & $\begin{array}{l}\text { Start } \\
\text { position }\end{array}$ & $\begin{array}{l}\text { Length } \\
\text { (bp) }\end{array}$ & $\begin{array}{l}\text { Primer } \\
\text { conc. }\end{array}$ & $\mathrm{Ta}$ & $\mathrm{Tm}$ & Slope \\
\hline \multirow[t]{2}{*}{ Mal d 1.01} & qMd1.01/02F & GATTGAAGGAGATGCTTTGACA & 5 & - & - & 258 & 103 & 100 & 63 & 80.5 & -0.079 \\
\hline & qMd1.01R & GTAATGACTGATGCTCTTGATGG & - & 1 & 1 & & & & & & \\
\hline \multirow[t]{2}{*}{ Mal d 1.02} & qMd1.01/02F & GATTGAAGGAGATGCTTTGACA & 4 & - & - & 258 & 111 & 100 & 62 & 81.0 & -0.206 \\
\hline & qMd1.02R & TTGGTGTGGTAGTGGCTGATA & 1 & 1 & - & & & & & & \\
\hline \multirow[t]{2}{*}{ Mal d $1.03 A$} & qMd1.03AF & ATCTGAGTTCACCTCCGTCATT & 1 & 2 & - & 21 & 96 & 70 & 63 & 81.0 & -0.057 \\
\hline & qMd1.03AR & ACTGCTTGTGGTGGAATCTTT & - & 1 & 1 & & & & & & \\
\hline \multirow[t]{2}{*}{ Mal d 1.03B } & qMd1.03BF & TGTITTCACATACGAATCCGA $\boldsymbol{A}$ & 1 & 1 & - & 6 & 167 & 100 & 63 & 83.5 & -0.570 \\
\hline & qMd1.03BR & TGATCTTCTTAATGGTTCCTACGC & 1 & 1 & 1 & & & & & & \\
\hline \multirow[t]{2}{*}{ Mal d $1.03 \mathrm{C}$} & qMd1.03CF & CTCCGAAACAATTGAGAAAATCTG & 3 & - & 1 & 276 & 79 & 100 & 63 & 80.5 & -0.120 \\
\hline & qMd1.03CR & GCTGGTGCTCTTGATGATGC & 1 & 1 & - & & & & & & \\
\hline \multirow[t]{2}{*}{ Mal d 1.03D } & qMd1.03D/EF & ATACGAATCCGAGTTCACCTCT & 1 & - & - & 15 & 156 & 70 & 62 & 83.0 & 0.005 \\
\hline & qMd1.03DR & ATCTTCTTAATGGTTCCAACTCCT & 1 & 1 & - & & & & & & \\
\hline \multirow[t]{2}{*}{ Mal d 1.03E } & qMd1.03D/EF & ATACGAATCCGAGTTCACCTCT & 1 & - & 2 & 15 & 169 & 70 & 62 & 83.0 & -0.116 \\
\hline & qMd1.03ER & TTCACCGAAGTTGATCTTCTTAATA & 1 & 1 & - & & & & & & \\
\hline \multirow[t]{2}{*}{ Mal d $1.03 F$} & qMd1.03FF & CACAGAATTGACGGGGTG & 2 & 2 & - & 208 & 119 & 70 & 63 & 81.0 & -0.122 \\
\hline & qMd1.03FR & CCGGAAGCGACCAACTTA & 2 & 1 & 1 & & & & & & \\
\hline \multirow[t]{2}{*}{ Mal d $1.03 \mathrm{G}$} & qMd1.03GF & ATTATCAAGAGCACCAGTCACTACT & 2 & 2 & - & 337 & 122 & 70 & 62 & 81.0 & -0.254 \\
\hline & qMd1.03GR & TCCAAGAGGTAGTTCTCAATCAA & 1 & - & - & & & & & & \\
\hline \multirow[t]{2}{*}{ Mal d $1.03 \mathrm{H}$} & qMd1.03HF & AAAATCTGCTACGAGACTAAGTTGA & 3 & 2 & - & 277 & 173 & 100 & 61 & 83.5 & -0.431 \\
\hline & qMd1.03HR & TGGTGCTCCAAGAGGTAGTTT & 1 & 1 & - & & & & & & \\
\hline \multirow[t]{2}{*}{ Mal d 1.03I } & qMd1.03IF & CCCCAAGATTGCACCACAT & - & 1 & - & 93 & 228 & 100 & 61 & 81.5 & -0.230 \\
\hline & qMd1.03IR & GCCACCAACTTAGTCTCGTAACA $\boldsymbol{A}$ & 2 & 1 & - & & & & & & \\
\hline \multirow[t]{2}{*}{ Mal d 1.03J } & qMd1.03JF & GCATCACCCACTACCACACA & 2 & 1 & - & 347 & 134 & 70 & 61 & 82.0 & -0.105 \\
\hline & qMd1.03JR & CGAGCTGTAGGAGTCTTGGTT & 3 & 3 & - & & & & & & \\
\hline \multirow[t]{2}{*}{ Mal d $1.03 \mathrm{~K}$} & qMd1.03KF & CATCAGCCACTACCACACAAA & 2 & 1 & - & 348 & 128 & 100 & 61 & 81.5 & -0.431 \\
\hline & qMd1.03KR & TGTATGCATCCTGGTGCTCT & 2 & 1 & 1 & & & & & & \\
\hline \multirow[t]{2}{*}{ Mal d 1.04} & qMd1.04F & GGGTATGTTAAGCAAAGGGTCA & 5 & 2 & - & 196 & 193 & 100 & 61 & 80.5 & -0.103 \\
\hline & qMd1.04R & TGATCTCAACATCACCCTTAGC & 1 & 1 & - & & & & & & \\
\hline \multirow[t]{2}{*}{ Mal d 1.05} & qMd1.05F & ATCAAACCACTAGTCACTGCCAT & 4 & 1 & 1 & 343 & 124 & 70 & 63 & 82.5 & -0.141 \\
\hline & qMd1.05R & GGTTGGCCACAAGGTAGGTT & 6 & 1 & - & & & & & & \\
\hline \multirow[t]{2}{*}{ Mal d 1.06A } & qMd1.06AF & CTATAGCTATAGCTTGATTGAAGGG & 5 & 1 & - & 243 & 167 & 100 & 61 & 80.5 & -0.203 \\
\hline & qMd1.06AR & TTCCAA_CCTTAACATGTTCTTCT & 3 & - & 1 & & & & & & \\
\hline \multirow[t]{2}{*}{ Mal d 1.06B } & qMd1.06BF & AAACCGAATACGCATCCATT & 3 & 3 & 1 & 20 & 106 & 100 & 61 & 81.5 & -0.012 \\
\hline & qMd1.06BR & ACAGTTTTGACTGCTTGTGGAG & 6 & - & - & & & & & & \\
\hline \multirow[t]{2}{*}{ Mal d $1.06 \mathrm{C}$} & qMald1.06CF & GCTCCACAAGCAGTCAAAACT & 5 & - & - & 103 & 116 & 70 & 63 & 80.5 & -0.250 \\
\hline & qMald1.06CR & TCAACCTTGTGCTTCACATAACTA & 3 & 2 & - & & & & & & \\
\hline \multirow[t]{2}{*}{ Mal d $1.06 \mathrm{D}$} & qMd1.06DF & ССCTCCTGCTAGGTTGTATT & 2 & 2 & - & 42 & 100 & 70 & 61 & 80.5 & -0.005 \\
\hline & qMd1.06DR & TCCCTCGAGAATTTCAACAG & 6 & - & - & & & & & & \\
\hline \multirow[t]{2}{*}{ Mal d 1.07} & qMd1.07F & CAACTTTGTGTACCAGTACAGTGTC & 2 & 2 & - & 234 & 126 & 100 & 61 & 81.5 & -0.201 \\
\hline & qMd1.07R & TAGTGGCTGATGCTCTTGATAAC & 2 & 1 & - & & & & & & \\
\hline \multirow[t]{2}{*}{ Mal d 1.08} & qMd1.08F & $\boldsymbol{T C T T C G G T G A A G G T A G C A C A \boldsymbol { A }}$ & - & 2 & - & 173 & 200 & 100 & 61 & 81.5 & -0.390 \\
\hline & qMd1.08R & ACCCTTAGTGTGGTAGTGGCAT & 1 & 2 & - & & & & & & \\
\hline Mal d 1.09 & qMd1.09F & TाTCACATACGAATCCGAGTC & - & 1 & - & 8 & 126 & 100 & 61 & 84.0 & -0.265 \\
\hline & qMd1.09R & GGATCTCAACGCTCTTCACA & 2 & 1 & - & & & & & & \\
\hline
\end{tabular}


Table $1 \mathrm{Mal} d$ 1specific primer pairs for qRT-PCR analysis (Continued)

\begin{tabular}{|c|c|c|c|c|c|c|c|c|c|c|c|}
\hline \multirow[t]{2}{*}{ Mal d 1.10.} & qMald1.10F & CAAGGCTITCATCCACGAC & 5 & 2 & 1 & 60 & 157 & 100 & 61 & 83.0 & -0.158 \\
\hline & qMald1.10R & GATTCTGTGCTTTACAAACCCT & 4 & 3 & - & & & & & & \\
\hline \multirow[t]{2}{*}{ Mal d 1.11A } & qMald1.11AF & GGAGGATGCATCTGTCATTTG & 11 & 1 & - & 343 & 130 & 100 & 62 & 79.5 & -0.018 \\
\hline & qMald1.11AR & CCATGAGATAGGCTTCCAAAACT & 8 & 2 & - & & & & & & \\
\hline \multirow[t]{2}{*}{ Mal d 1.11B } & qMd1.11BF & CAGCACATACAAAGCCAAAGAC & 8 & 1 & - & 363 & 125 & 100 & 61 & 81.0 & -0.106 \\
\hline & qMd1.11BR & TTTATGCGCGAGGGTGTG & 6 & 1 & - & & & & & & \\
\hline \multirow[t]{2}{*}{ Mal d 1.12} & qMd1.12F & GCTTACACTTTGGITGAAGGAGAAC & 4 & 3 & - & 247 & 171 & 100 & 62 & 76.0 & -0.227 \\
\hline & qMd1.12R & СCTGCCAGCTITTATTTCTTCC & 5 & 4 & - & & & & & & \\
\hline \multirow[t]{2}{*}{ Mal d $1.13 A$} & qMd1.13AF & GTGTTGGAACCATCAAGAAGATTAG & 2 & 2 & - & 149 & 124 & 100 & 61 & 78.0 & -0.216 \\
\hline & qMd1.13AR & ACATCTCCTTCAATCAAACTGTAAT & 1 & 1 & - & & & & & & \\
\hline \multirow[t]{2}{*}{ Mal d $1.13 B$} & qMd1.13BF & CGAAGATAACTITGTCTACAACCAT & 2 & 1 & - & 258 & 137 & 70 & 61 & 81.5 & 0.003 \\
\hline & qMd1.13BR & GCTCTTCCTTGATCTCAACATCTT & 1 & 1 & - & & & & & & \\
\hline \multirow[t]{2}{*}{ Mal d $1.13 \mathrm{C}$} & qMd1.13CF & GAATTCGCCTCAGTCTCCA & 5 & 1 & - & 25 & 186 & 70 & 61 & 82.0 & 0.087 \\
\hline & qMd1.13CR & GTGCTTCACATAGCTGTATTCACTT & 3 & 1 & - & & & & & & \\
\hline \multirow[t]{2}{*}{ Mal d 1.13D } & qMd1.13DF & TGTTGGAACCATCAAGAAGATAAGT & 2 & 1 & - & 150 & 124 & 100 & 61 & 78.5 & -0.163 \\
\hline & qMd1.13DR & GACATCTCCTTCAATCAAACTGTAG & 2 & 1 & - & & & & & & \\
\hline \multirow[t]{2}{*}{ Mal d 1.14} & qMd1.14F & GGTGAAGGGAGTGAATACAACTATA & 6 & 1 & - & 178 & 185 & 100 & 61 & 79.0 & -0.470 \\
\hline & qMd1.14R & TGGTAATGGCTAAATGTTCTTGATAC & 2 & 2 & 2 & & & & & & \\
\hline
\end{tabular}

${ }^{a}$ SNPs to the consensus sequence showed in bold; ${ }^{b}$ gene-differentiating SNPs showed in italics and callele-differentiating SNPs showed by underlining. The last column contains the slopes of the curves obtained by plotting log input vs $\Delta \mathrm{Ct}$ (Ct Mal $d 1$ gene - Ct actin). The values between -0.1 and 0.1 are underlined.

obtained after increasing the annealing temperature (Ta) within the range of $61-63^{\circ} \mathrm{C}$ and/or decreasing the final primer concentration from $100 \mathrm{nM}$ to $70 \mathrm{nM}$. Some of the amplicon sequences revealed new Mal $d 1$ alleles for the known genes (Additional file 3). Fourthly, the amplification specificity was validated through melting curves obtained with a single high peak (Figure 3), indicating the absence of nonspecific amplifications or primer dimers. The primer pairs that met this last criterion were selected for the qRT-PCR assay. The melting temperatures $(\mathrm{Tm})$ for these primers are reported in Table 1.

Expectedly, significant variations in PCR efficiency were detected among the Mal $d 1$ amplicons (Table 1, slopes in the last column) due to the forced positions of the primers to the targeted SNPs and variations in the PCR conditions to ensure specificity. However, the "Standard curve method" was chosen to neutralise these differences in efficiency. Particularly, this method has to be used when the slope values of the curves obtained by plotting log input vs dCt (Ct Mal $d 1$ gene - Ct actin) are outside the -0.1 to 0.1 range [23], as in the case of this study (Table 1 ). The standard curves were of high quality, as a linear relationship between the input DNA and the Ct values across the standard samples (serial dilutions) was observed, with a squared regression coefficient close to 1 for all genes. Moreover, the use of standard samples in all the qRT-PCR reactions facilitated the evaluation of the reproducibility among experiments and the integration of the data.
Finally, the comparison of the gene expression in 'Florina' and 'Gala' of actin, $U B C$ and GAPDH was performed in order to choose the most suitable reference gene for this study. Actin showed a highly stable expression among tissues and cultivars (Figure 4) and thus, it was an optimal reference gene for this study.

\section{Application: Mal $d 1$ expression profiles in different apple tissues}

In this study, we applied this new qRT-PCR assay to the peel and flesh of apple fruits from the cultivars 'Florina' and 'Gala'. These two cultivars were selected because they differ in their allergenic characteristics in skin prick tests [24]. Moreover, both cultivars have been extensively used in the breeding of new apple cultivars and are subject to GM studies concerning the enhancement of 'Gala' resistance to the main disease in apple production, the fungus Venturia inaequalis, through gene transfer without raising Mal d 1 levels [25].

Among the $31 \mathrm{Mal} d 1$ genes, 11 were not expressed in any fruit tissue. These genes included all of the genes of subfamily II and several genes of subfamilies III and IV (respectively Mal $d 1.06 D,-1.13 C$ and -1.14 , and Mal d 1.03B, -1.03H, -1.03I, -1.03J, and -1.09) (Figure 5). The 20 genes expressed in these fruits included all of the genes of subfamilies I and V and some of the genes of subfamilies III and IV (respectively Mal $d$ 1.06A, -1.06B, $1.06 C,-1.13 A,-1.13 B,-1.13 D$ and $-1.03 A,-1.03 C,-1.03 D$, $1.03 E,-1.03 K,-1.03 F,-1.03 G,-1.07,-1.08)$. A significant 

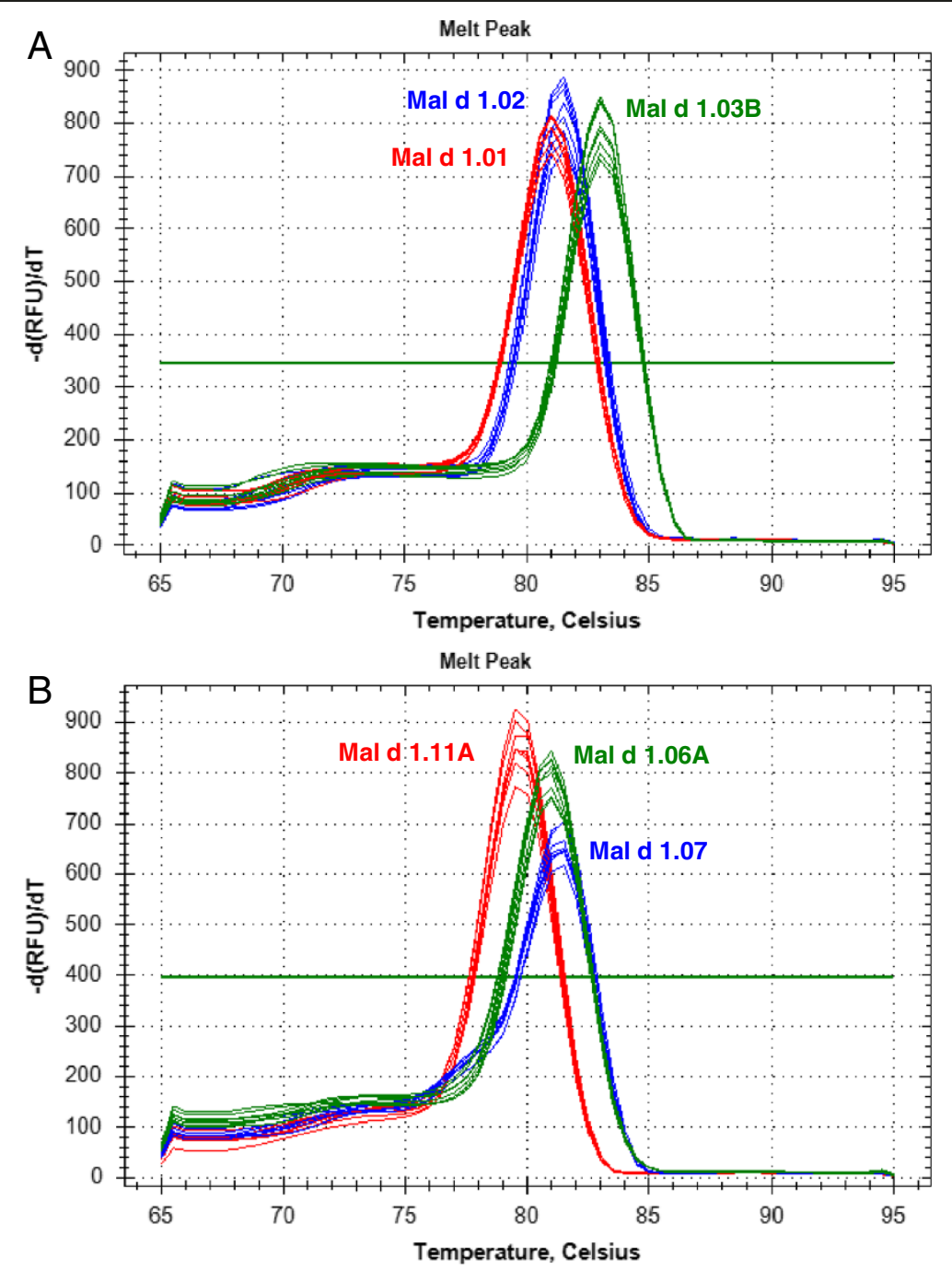

Figure 3 Melting curve analyses of two different qRT-PCR reactions. The negative first derivative of the change in fluorescence is plotted as a function of temperature. The single peak for each primer pair indicates the presence of only one PCR product. A) Melting curves for Mal $d 1.01$ (red), Mal d 1.02 (blue) and Mal d 1.03B (green) amplicons. B) Melting curves for Mal d 1.11A (red), Mal d 1.07 (blue) and Mal d 1.06A (green) amplicons.

variation in the transcript level among genes, tissues and cultivars was observed $(\mathrm{P}<0.0001)$.

Concerning the variations in expression among the genes, the two genes of subfamily I (Mal $d 1.01$ and -1.02) showed the highest expression level, which were 10 to 10,000 times higher than any other Mal $d 1$ gene, and the combined total amount of RNA for these genes exceeded the amount of all other genes combined. Mal $d 1.01$ was the most expressed gene, with a normalised expression of approximately 60 A.U. in the fruit peel of 'Florina'. Mal $d$ $1.03 \mathrm{C}$ was least expressed gene, with a transcript level close to the limit of detection.

The variations in gene expression between fruit tissues were evident, with the expression in the apple peel being significantly higher than in the flesh for both cultivars. The genes of subfamily $\mathrm{V}$ were the only exception, as
Mal $d 1.11 A$ and $-1.11 B$ showed similar levels of expression in the peel and flesh, and Mal d 1.12 was more expressed in the flesh than in the peel in 'Gala' fruits.

A comparison of the two cultivars revealed that 'Florina' generally shows a higher level of expression than 'Gala', which was consistent with a previous study on the expression of a limited number of Mal $d$ genes [19]. Specifically, for 15 out of 20 genes, the expression was higher in 'Florina', with an average increase of $60 \%$. The remaining 5 genes, Mal $d 1.03 \mathrm{~A},-1.03 \mathrm{~K},-1.06 \mathrm{~A},-1.06 \mathrm{C}$ and -1.07 , belonging to subfamilies III and IV, were more expressed in 'Gala' than in 'Florina'.

\section{Discussion}

The results obtained from the assay described in this paper provided insight into the role of individual isoallergens in 


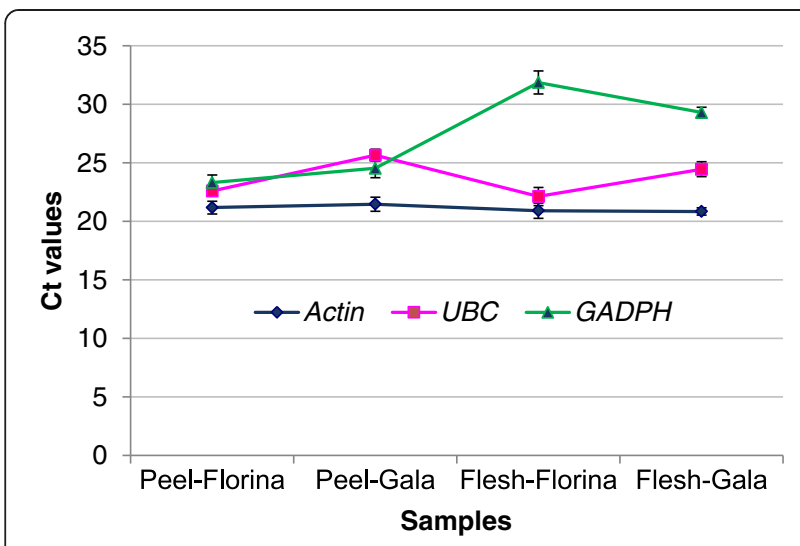

Figure $4 \mathrm{Ct}$ values of three putative reference genes in 'Florina' and 'Gala' peel and flesh. The Ct values obtained after qRT-PCR amplification with the primers for actin, UBC and GAPDH in 'Florina' and 'Gala' samples are plotted in the chart. Each data point is the average of two biological replicates and the bars indicate the standard deviation.

Mal d 1-related apple allergy. The assay was based on a complete set of primers that were suitable for expression studies for each Mal $d 1$ isoallergen gene using qRT-PCR. All primers passed several assessments of validation and optimisation and can now be used in a broad range of experiments. This approach can be relatively quickly adopted to other crops whose allergen genes have been mapped, a reference genome sequence is available and some knowledge of the genes and allelic diversities is available, such as for the peach Pru $p 1$ genes [6,22,26].

\section{The qRT-PCR assay}

The study of gene expression is an informative approach, and the first application of this assay confirmed Mal $d 1$ as a heterogeneous family of genes that show distinct expression patterns despite having highly similar sequences. For single copy genes, the qRT-PCR technique is a highly sensitive and reproducible technique, with a large dynamic range compared with microarray approaches [23], without requiring a strong knowledge of bioinformatics, expensive equipment or particular expertise. qRT-PCR is also relatively cheap, particularly when SYBR green chemistry is used, as in this study, initial accurate primers are selected and an appropriate methodology is employed. Here we demonstrated the suitability of qRT-PCR for the assessment of a large gene family, whereby we obtained gene specificity through the use of sequence polymorphisms at the $3^{\prime}$ end of at least one of the two primers and stringent PCR conditions.

The calibration method can seriously affect the results of qRT-PCR based assays. The "Standard curve method" accounts for variations in PCR efficiency among primer pairs [23], thus facilitating the comparison and integration of data from different primer pairs and experiments. The only disadvantage is the need to include a series of standard samples in each qRT-PCR experiment for all the tested genes, including reference gene, thereby slightly increasing cost and time compared with other methods.

\section{Clarifying the role of individual genes}

Small changes in protein sequences might result in large differences in allergenic characteristics. A single amino acid change at a critical position in the epitope formation might completely alter the allergenicity of Mal $\mathrm{d} 1$ proteins [27-29]. For Bet $\mathrm{v} 1$, a difference of 7 amino acids between two isoallergens resulted in large differences in their allergenic and immunogenic properties: Bet $\mathrm{v} 1.0101$ acted as a strong sensitiser, whereas Bet v 1.0401 was clearly associated with weaker IgE responses [30]. A similar situation likely exists in the apple, implying the existence of naturally hypoallergenic Mal d 1 isoallergens that induce no or mild IgE responses in allergic individuals. Currently, the allergenicity of single Mal d 1 isoallergens and their variants remains undetermined. Previous studies using gene expression approaches to obtain information on the differential expression within this gene family have characterised Mal d 1.02 as the most expressed isoallergen gene [17-20]. However, our assay is a crucial step towards the identification of specific candidate genes for allergenicity within the Mal $d 1$ family through an assessment of the presence and unequal dispersion of all the Mal $d 1$ gene transcripts in apple fruits, thereby correlating differences in allergenicity among cultivars with differences in the expression of individual genes.

Indeed, the results obtained from the first application of this assay showed that 11 of the $31 \mathrm{Mal} d 1$ genes were not expressed in 'Florina' and 'Gala' fruit. Therefore, the genes encoding these isoallergens are not involved in the allergenicity of 'Florina' and 'Gala' fruits and reasonably in the allergenicity of other cultivars, reducing the number of candidates for further assessments. This result is consistent with studies conducted in birch, where the Bet $v 1$ genes from only two of 5 subfamilies were expressed in pollen [31].

Among the 20 isoallergen genes that were expressed, we observed a large variation in expression between the tissues, genes and cultivars. We detected a higher expression of Mal $d 1$ genes in the peel than in the flesh. Therefore, it is reasonable to assume that peeling of apple fruits would remove most of the Mal d 1 proteins. Nevertheless, peeling was helpful to a small portion of the apple allergic population [32], indicating that we cannot a priori exclude isoallergen genes based solely on their levels of expression. Indeed, a small amount of a highly allergenic isoform might provoke allergy due to high immune reactivity, whereas large amounts of low-immune-reactive or nonimmune-reactive isoallergens might provoke no allergic responses [14]. Thus, isoallergens, such as Mal d 1.11B, 


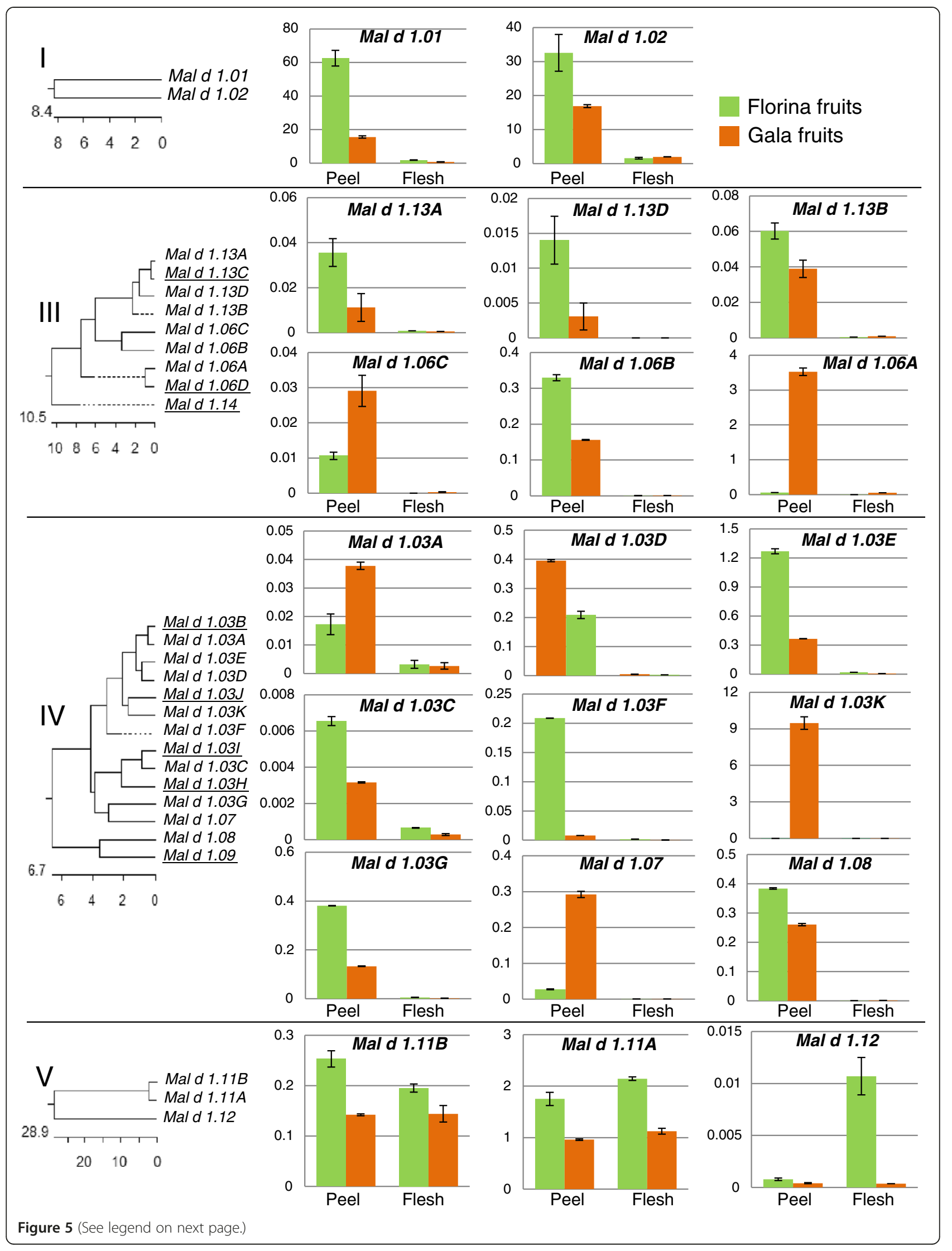


(See figure on previous page.)

Figure 5 Expression profiles of the Mal $\boldsymbol{d} \mathbf{1}$ genes in the peel and flesh of apple fruits. The genes were grouped into subfamilies and reported according to the order obtained in the phenetic tree. The branches of the phenetic trees for each subfamily (I-V) are reported on the left. The underlined genes were not expressed (charts not reported: subfamily II was not reported because none of its genes were expressed). The green bars indicate the results for 'Florina', and the orange bars indicate the results for 'Gala'. The expression levels were normalised in respect to actin and reported in Arbitrary Units (A.U.). Each data point is the average of the final expression values of two biological replicates.

which are equally expressed in the peel and flesh, should receive full attention, despite being expressed approximately 300 times less than Mal d 1.01. However, for individuals for which peeling fruit is helpful, we can further limit the number of potentially involved genes to those that are only expressed in the peel.

Apple cultivars differ in allergenicity according to oral provocations and skin prick tests $[2,3]$. The current assay improved our understanding of these differences, facilitating the correlation of expression profiles across Mal $d 1$ genes to allergy responses across cultivars. 'Florina' exhibited lower skin prick test responses than 'Gala' in prick-to-prick tests on whole fruits [24]. Most of the Mal $d 1$ isoallergen genes were more expressed in the less allergenic cultivar 'Florina', suggesting that these genes play a minor role in allergy, whereas genes that are more expressed in 'Gala' could receive priority for further analysis (i.e., Mal d 1.06A, - 1.06C, -1.03A, -1.03K and - 1.07). The indication for Mal 1.06A is of special interest, as a possible role for this isoallergen has been previously suggested [8] based on a correlation between the allelic composition of Mal d 1.06A and the level of allergenicity of a small set of apple cultivars. Extending the application of our qRT-PCR assay to a broader set of cultivars with known allergenicities will provide further insight into this phenomenon. We are currently applying this approach to apple fruits in which the expression of a range of Mal $d 1$ genes is supposedly silent [33,34] and for which the data from oral provocations are available (unpublished observations). Even if there is a general good correlation between proteins and transcripts abundance [35], quantitative information about protein content would be highly desirable. It is always difficult to analyse specific protein isoforms in the case of protein families, in particular for Mal d 1 because of their sensitive 3D structure [9]. Despite that, thanks to this work it will be possible to focus the protein studies only on the interesting proteins, trying to develop Mal d 1 isoallergens-specific IgE.

Immunotherapy can be effective for respiratory-based allergies, but studies have presented contradictory results for food allergies. The apple allergy cross-reactivity between pollen and foods has been exploited, but the effectiveness of pollen allergen immunotherapy on allergies to cross-reactive foods has not been confirmed [36]. Oral desensitisation treatment has also been examined for the first time, with promising results, using a mixture of fresh fruits from different cultivars [37]. Our assay might facilitate the further development of immunotherapies, as the allergy causing isoallergens could be identified at the individual level, thus leading to personalised proteins for use in immunotherapy. Beyond immunotherapy, our assay might also provide information for personalised diagnostics and recommendations on the safe consumption of specific cultivars.

\section{Regulation of gene expression and the biological roles of Mal d 1}

The Mal $d 1$ genes are grouped into subfamilies based on similarities in their genomic and amino acid sequences [6]. This grouping is consistent with similarities in the expression profiles of these genes. Similar expression profiles were observed: i) all the genes of subfamily II were not expressed in fruit; ii) the two genes of subfamily I were both highly expressed and iii) the genes of subfamily $\mathrm{V}$ were equally expressed in the peel and flesh, suggesting sequence similarities in the promoter regions of these genes.

The biological role of Mal d 1 proteins in plants remains unclear. These proteins are activated in response to many different abiotic and biotic stresses $[38,39]$ and play a putative role in plant defence responses to pathogens $[17,40,41]$. Indeed, Mal $\mathrm{d} 1$ proteins are also known as pathogenesisrelated proteins of class 10 (PR-10s) [41]. However, the specific Mal $d 1$ genes involved in stress responses have not been identified and whether these genes are the same genes involved in allergy remains unknown. Thus, it is critical to determine whether breeding for low allergenicity would have consequences in terms of plant susceptibility against pathogens or abiotic stresses and whether high resistance to stresses would have consequences in terms of allergenicity. In addition, other stresses associated with growth and storage conditions affect the Mal d 1 content in apples $[2,3,42]$. Therefore, exploiting our set of primers to study the variation of gene expression at different pre-/post-harvest conditions or after exposure to biotic/abiotic stresses might contribute to defining a "hypoallergenic protocol" for apple production to favour the reduction of symptoms in patients with apple allergies.

\section{Conclusions}

To date, patients with apple allergies deal with these condition through avoidance. To facilitate the normal consumption of essential components of a healthy diet containing apples, it will be useful to produce 'allergyfriendly' fruit. To obtain this goal, knowledge of the 
identification of Mal d 1 isoallergens that cause allergy is needed. The qRT-PCR assay described in this work facilitates the examination of individual genes. The first application of this qRT-PCR assay showed that only a portion of the Mal $d 1$ genes is expressed in fruit. Moreover, the expressed genes showed great variation in expression among different tissues and cultivars. The data indicate that the presence and amount of specific Mal d 1 isoallergens determines allergenicity rather than total Mal d 1 content. For genes of specific interest, this assay might be further developed for allele (variant)-specific primer pairs, which, in turn, will promote the breeding of hypo-allergenic apple genotypes and support specific recommendations for fruit consumption, thereby reducing the impact of fruit allergies in a patient's life.

\section{Methods}

\section{Retrieval of Mal $d 1$ sequences and their alignment}

For the development of gene-specific primer pairs, all available sequence information for Mal $d 1$ was used at both the gene and allele levels. Coding DNA sequences (cds) were retrieved from the literature [6-8,17,19], the 'Golden Delicious' genome sequence [22,43] and a BLASTN search in the NCBI database [44] using keywords and Mal $d 1$ sequences as inputs. The coding sequences of $31 \mathrm{Mal} d 1$ genes from the genome sequence of 'Golden Delicious' [6] were aligned using the Lasergene v8.0, MegAlign package (DNASTAR, Madison, WI, USA) and manually adjusted where necessary. A phenetic tree was produced using the same software, with default parameters and a neighbour-joining cluster algorithm (NJ). Single Nucleotide Polymorphisms (SNPs) among the different Mal d 1 sequences were identified. Subsequently, a complete alignment of all available Mal $d 1$ sequences was generated, and gene- and allele-differentiating SNPs were identified.

\section{Gene-specific primer design and validation}

Gene-specific primer pairs were designed using the software Primer3 [45]; the targeted gene-differentiating SNPs were located at the $3^{\prime}$ end of at least one of the two primers (see Table 1) to ensure the primer's ability to specifically amplify the target gene and, particularly, all known alleles of that target locus. Other criteria in the primer design included a primer length of 18-24 nucleotides, a guanine-cytosine content of $20-80 \%$ and a RT-PCR amplicon length of 80-200 base pairs. Each primer pair was tested for the formation of homo- and heterodimers using the software PrimerSelect of Lasergene v8.0 (default settings).

The gene specificity of each primer pair was validated in four ways. Firstly, for the in silico analysis, the primer sequences were blasted against the reference 'Golden
Delicious' apple genome and the NCBI database. Secondly, to validate the primer specificity, the presence of a single PCR product after end-point PCR on genomic DNA was assessed. The PCR reactions were performed in a $17.5 \mu \mathrm{l}$ volume containing $10 \mathrm{ng}$ of DNA, $100 \mathrm{nM}$ of gene-specific primers, $1 \mathrm{X}$ reaction buffer, $1.5 \mathrm{mM} \mathrm{MgCl}$, $100 \mu \mathrm{M}$ dNTPs and 0.5 Unit AmpliTaq Gold $^{\circledR}$ DNA Polymerase (Applied Biosystems, Foster City, CA, USA). The reaction included an initial $10 \mathrm{~min}$ denaturation step at $95^{\circ} \mathrm{C}$, followed by $33 \mathrm{PCR}$ cycles $\left(45 \mathrm{sec}\right.$ at $60^{\circ} \mathrm{C}$, $2 \mathrm{~min}$ at $72^{\circ} \mathrm{C}$, and $30 \mathrm{sec}$ at $95^{\circ} \mathrm{C}$ ), with a final extension of $7 \mathrm{~min}$ at $72^{\circ} \mathrm{C}$. The amplicons were visualised on an Image Station 440 CF (Kodak, Rochester, N.Y., USA) after electrophoresis on $1.5 \%(\mathrm{w} / \mathrm{v})$ agarose gels and ethidium bromide staining. When non-specific bands were detected, the PCR conditions (primers concentration and annealing temperature) were optimised to obtain a single band. Thirdly, the primer specificity was validated through direct sequencing of all the amplicons from the gDNA of a set of 10 cultivars: 'Florina,' 'Gala, 'Santana,' 'Elstar,' 'Elise,' 'Golden Delicious,' 'Prima,' 'Jonathan, 'Cox' and 'Ingrid Marie'. The sequencing reactions were performed at Bio-Fab Research, Pomezia, Italy and Greenomics, Wageningen, The Netherlands. The samples included tissues from low ('Elise' and 'Santana') and high ('Golden Delicious') allergenic apple cultivars [2,3,46], that have been used in other studies of apple allergenicity and in studies on the effects of genetic modification on the expression of allergen genes ('Florina' and 'Gala') [24,25]. Cultivars currently used in apple breeding ('Cox', 'Elstar', 'Golden Delicious', 'Jonathan' and 'Prima') were also included in these assessments. Subsequently, these sequences were analysed using Chromas Lite v.2.01, BLAST and MegAlign. Fourthly, the primer specificity was validated through qRT-PCR, using the shape of the melting curve as a criterion. Due to variations in length and nucleotide composition, each unique product was expected to have a unique melting temperature (Tm) and, consequently, a unique melting (or dissociation) curve. If the primer pair produced a single amplicon, the plot of the first derivative of the melting curve would contain a single sharp peak.

\section{Plant material, RNA extraction and CDNA synthesis}

The developed qRT-PCR assay was applied to the fruits of two apple cultivars ('Florina' and 'Gala'). The fruits were collected at the Cadriano Experimental Orchard of the University of Bologna (Italy) at the physiological ripening stage. For each genotype peel and flesh from 5 apples were separately pooled, frozen in liquid nitrogen and stored at $-80^{\circ} \mathrm{C}$ until RNA extraction. In particular, the peel was carefully separated from the flesh, leaving only a thin layer of flesh attached to the peel. Two different RNA extractions (biological replicates) were performed 
from each pool. The cDNA was synthesised according to previously published methods [19].

\section{Absolute quantification of the expression levels of the Mal $d 1$ genes}

Expression of Mal $d 1$ genes was characterised through qRT-PCR using a StepOne Plus Real-Time PCR instrument (Applied Biosystems) with a SYBR green-based assay. Similar to all other intercalating dyes, SYBR green binds to any double-stranded DNA; therefore, the specificity of the primers was carefully assessed. Each reaction was performed in a total volume of $10 \mu \mathrm{l}$, containing 5 $\mu$ l of Power SYBR ${ }^{\circledR}$ Green Master Mix 2X, 70-100 nM of each primer, $3 \mu \mathrm{l}$ of a 1:9 dilution of the cDNA and PCR-grade water. The reactions were incubated at $50^{\circ} \mathrm{C}$ for $2 \mathrm{~min}$ and at $95^{\circ} \mathrm{C}$ for $5 \mathrm{~min}$, followed by 40 cycles of $95^{\circ} \mathrm{C}$ for $15 \mathrm{sec}$ and $60 / 63^{\circ} \mathrm{C}$ for $1 \mathrm{~min}$, with data collection at each annealing step. The reactions were performed in triplicate (technical replicates). To ensure the specificity of the amplifications, each amplification reaction was followed by a melting phase, according to the default settings of the Step One Plus instrument (from $60^{\circ} \mathrm{C}$ to $95^{\circ} \mathrm{C}$ ) and each melting curve was assessed for the presence of a single peak. The qRT-PCR assay included a standard curve for each target gene in the plate. Each standard curve comprised 6 serial 1:10 dilutions (in duplicate) of the amplicons obtained from a fixed amount of gDNA using gene-specific primers, starting from $100 \mathrm{ng}$. The curve correlated fluorescence signal (expressed as Ct values) to known amounts of amplicons in the 6 serial dilution samples and a regression line was plotted. Each assay also included a negative control performed in duplicate. The shape of the melting curves obtained from the standard curve dilutions (gDNA) and the samples (cDNA) indicates whether the amplified products are homogeneous and the melting temperature provides confirmation that the correct product has been specifically amplified.

The amplification efficiency (E) of each primer pair was estimated using the slope of the regression line, according to the equation: $\mathrm{E}=10^{(-1 / \text { slope })}-1$ [47]. The relative PCR efficiencies were evaluated for each target gene in relation to the reference gene to select an appropriate method for the analysis of the raw qRT-PCR data. To obtain the gene expression results, the raw data was transformed using the "Standard curve method" [23] and reported as relative expression levels; the transcript levels of the Mal $d 1$ genes were normalised to the transcript levels of actin (primer sequences from [48]) and expressed as Arbitrary Units (A.U.). Actin was chosen after the comparison of its gene expression to other two putative reference genes: (1) UBC (UBiquitin-Conjugating enzyme, MDP0000223660), forward primer 5'-CGAATTTGTCCG AAGGCGT-3'; reverse primer: 5'-CAATGATTGTCACAG CAGCCA-3', and (2) GAPDH (Glyceraldehyde 3-phosphate dehydrogenase, MDP0000835914), forward primer 5'-ATT GGCAGTGTGCGACGTT-3' and reverse primer $5^{\prime}$-GGA GGAGTCAATGGTGGAGGA-3'). The comparison of the three putative reference genes was done in two biological replicates of peel and flesh of 'Florina' and 'Gala'. The mean normalised expression levels and the standard error of the mean (SEM) were calculated using the two biological replicates. Univariate analyses of the differences between the mean values were performed using analysis of variance (ANOVA) with a 0.05 significance level.

\section{Additional files}

\begin{abstract}
Additional file 1: List of $\mathrm{Mal} d 1$ sequences included in the alignment.

Additional file 2: Alignment of the $\mathbf{3 1}$ coding sequences of the $\mathrm{Mal}$ $\boldsymbol{d} 1$ isoallergen genes. Alignment of the 31 coding sequences of the Mal $d 1$ isoallergen genes retrieved from the 'Golden Delicious' genome sequence. The alignment was performed using MegAlign (DNASTAR Lasergene v8.0). Each sequence was reported using the name of the related gene and the accession number from the Apple GBrowse - Malus $x$ domestica $v 1.0$ [22]. The mismatched residues in the consensus sequence are highlighted in white.

Additional file 3: Results of direct sequencing. The results of the BLASTN analysis of the sequences retrieved from the direct sequencing of Mal d 1 amplicons from 10 different apple cultivars. The table lists the targeted gene, the name of the primer pair and the ID of the most similar sequence in the database or in the Gbrowse of the apple genome for each of the cultivars [22]; the presence/absence of the SNPs in these reference sequences is also indicated.
\end{abstract}

\section{Authors' contributions}

GP and RP: participated equally in the design of the study, carried out the molecular genetic studies, participated in the sequence alignment, performed the statistical analysis and drafted the manuscript. PA and ST: participated in the design of the study and critically read the manuscript. GR: participated in the design and coordination of the work. MJMS: critically read the manuscript. WEW: participated in the design and coordination of the work and helped to draft the manuscript. All authors read and approved the final manuscript.

\section{Acknowledgements}

This research was financially supported through grants from the ISAFRUIT Project through the European Commission under the Thematic Priority 5 Food Quality and Safety of the 6th Framework Programme of RTD (Contract No. FP6-FOOD-CT-2006-016279). The views and opinions expressed in this publication are solely those of the writers and do not under any circumstances reflect the official position of the European Commission.

\section{Author details}

${ }^{1}$ Wageningen UR Plant Breeding, Plant Research International, Droevendaalsesteeg 1, Wageningen, PB 6708, The Netherlands. ${ }^{2}$ Department of Fruit Tree and Woody Plant Sciences, University of Bologna, Viale Fanin 46, Bologna 40127, Italy. ${ }^{3}$ Department of Paediatrics, University of Bologna, Via Massarenti 11, Bologna 40138, Italy. ${ }^{4}$ Present address: Consiglio per la Ricerca e la sperimentazione in Agricoltura-Centro di Ricerca per le Colture Industriali, via di Corticella 133, Bologna 40128, Italy.

Received: 1 October 2012 Accepted: 14 March 2013

Published: 23 March 2013

\section{References}

1. Burney P, Summers C, Chinn S, Hooper R, van Ree R, Lidholm J: Prevalence and distribution of sensitization to foods in the European community respiratory health survey: a EuroPrevall analysis. Allergy 2010, 65:1182-1188. 
2. Bolhaar ST, van de Weg WE, van Ree R, Gonzalez-Mancebo E, Zuidmeer L, Bruijnzeel-Koomen CA, Fernandez-Rivas M, Jansen J, Hoffmann-Sommergruber K, Knulst AC, Gilissen LJ: In vivo assessment with prick-to-prick testing and double-blind, placebo-controlled food challenge of allergenicity of apple cultivars. J Allergy Clin Immunol 2005, 116:1080-1086.

3. Vlieg-Boerstra BJ, van de Weg WE, van der Heide S, Kerkhof M, Arens P, Heijerman-Peppelman G, Dubois AE: Identification of low allergenic apple cultivars using skin prick tests and oral food challenges. Allergy 2011, 66:491-498

4. Vanek-Krebitz M, Hoffmann-Sommergruber K, Laimer da Camara Machado M Susani M, Ebner C, Kraft D, Scheiner O, Breiteneder H: Cloning and sequencing of Mal d 1, the major allergen from apple (Malus domestica), and its immunological relationship to Bet $v 1$, the major birch pollen allergen. Biochem Biophys Res Commun 1995, 214:538-551.

5. Fernández-Rivas M, Bolhaar S, González-Mancebo E, Asero R, van Leeuwen A, Bohle B, Ma Y, Ebner C, Rigby N, Sancho Al, Miles S, Zuidmeer L, Knulst A, Breiteneder H, Mills C, Hoffmann-Sommergruber K, van Ree R: Apple allergy across Europe: how allergen sensitization profiles determine the clinical expression of allergies to plant Foods. J Allergy Clin Immunol 2006, 118:481-488.

6. Pagliarani G, Paris R, lorio AR, Tartarini S, Del Duca S, Arens P, Peters S, van de Weg E: Genomic organisation of the Mal d 1 gene cluster on linkage group 16 in apple. Mol Breed 2012, 29:759-778.

7. Gao ZS, van de Weg WE, Schaart JG, Schouten HJ, Tran DH, Kodde LP, van der Meer IM, van der Geest AH, Kodde J, Breiteneder H, HoffmannSommergruber K, Bosch D, Gilissen L: Genomic cloning and linkage mapping of the Mal d 1 (PR-10) gene family in apple (Malus domestica). Theor Appl Genet 2005, 111:171-183.

8. Gao Z, van de Weg EW, Matos Cl, Arens P, Bolhaar ST, Knulst AC, Li Y, Hoffmann-Sommergruber K, Gilissen LJ: Assessment of allelic diversity in intron-containing Mal d 1 genes and their association to apple allergenicity. BMC Plant Biol 2008, 13:116.

9. Bohle B, Zwölfer B, Heratizadeh A, Jahn-Schmid B, Antonia YD, Alter M, Keller W, Zuidmeer L, van Ree R, Werfel T, Ebner C: Cooking birch pollenrelated food: divergent consequences for IgE- and T cell-mediated reactivity in vitro and in vivo. J Allergy Clin Immunol 2006, 118:242-249.

10. Marzban G, Mansfeld A, Hemmer W, Stoyanova E, Katinger H, da Câmara Machado ML: Fruit cross-reactive allergens: a theme of uprising interest for consumers' health. Biofactors 2005, 23:235-341.

11. Zuidmeer L, van Leeuwen WA, Kleine Budde I, Breiteneder H, Ma Y, Mills C, Sancho Al, Meulenbroek EJ, van de Weg E, Gilissen L, Ferreira F, Hoffmann-Sommergruber $K$, van Ree R: Allergenicity assessment of apple cultivars: hurdles in quantifying labile fruit allergens. Int Arch Allergy Immunol 2006, 141:230-240.

12. Herndl A, Marzban G, Kolarich D, Hahn R, Boscia D, Hemmer W, Maghuly F, Stoyanova $\mathrm{E}$, Katinger $\mathrm{H}$, Laimer M: Mapping of Malus domestica allergens by 2-D electrophoresis and IgE-reactivity. Electrophoresis 2007, 28:437-448.

13. Rur M: Localization of the main allergy protein in two apple cultivars grown in Sweden. Swedish University of Agricultural Sciences. Department of Crop Production Ecology 2007:03. ISSN 1652-1579.

14. Schenk MF, Cordewener JH, America AH, Peters J, Smulders MJ, Gilissen LJ: Proteomic analysis of the major birch allergen Bet $\mathrm{v} 1$ predicts allergenicity for 15 birch species. J Proteomics 2011, 74:1290-1300.

15. Ballmer-Weber BK, Hoffmann-Sommergruber K: Molecular diagnosis of fruit and vegetable allergy. Curr Opin Allergy Clin Immunol 2011, 11:229-235.

16. Sancho Al, Mills EN: Proteomic approaches for qualitative and quantitative characterisation of food allergens. Regul Toxicol Pharmacol 2010, 58:S42-S46.

17. Beuning LL, Bowen JH, Persson HA, Barraclough D, Bulley S, MacRae EA: Characterisation of Mal d 1-related genes in Malus. Plant Mol Biol 2004, 55:369-388.

18. Puehringer $H$, Zinoecker I, Marzban $G$, Katinger $H$, Laimer M: MdAP, a novel protein in apple, is associated with the major allergen Mal d 1. Gene 2003, 321:173-183.

19. Pagliarani G, Paris $R$, Tartarini S, Sansavini S: Cloning and expression of the major allergen genes in apple fruit. J Hortic Sci Biotech 2009, ISAFRUIT Special Issue:176-181.

20. Botton A, Lezzer P, Dorigoni A, Barcaccia G, Ruperti B, Ramina A: Genetic and environmental factors affecting allergen-related gene expression in apple fruit (Malus domestica L. Borkh). J Agric Food Chem 2008, 56:6707-6716.

21. Iorio RA, Di Sandro A, Paris R, Pagliarani G, Tartarini S, Ricci G, SerafiniFracassini D, Verderio E, Del Duca S: Simulated environmental criticalities affect transglutaminase of Malus and Corylus pollens having different allergenic potential. Amino Acids 2012, 42:1007-1024.

22. The Genome Database for Rosaceae (GDR). www.rosaceae.org

23. Larionov A, Krause A, Miller W: A standard curve based method for relative real time $P C R$ data processing. BMC Bioinforma 2005, 6(Larionov A, Krause A, Miller W):62.

24. Ricci G, Dondi A, Belotti T, Baldi E, Tartarini S, Paris R, Pagliarani G, SerafiniFracassini D, Casadio R, Giannetti A, Masi M: Allergenicity of different apple cultivars assessed by means of skin prick test and sensitisation to recombinant allergens $\mathrm{Mal} d \mathrm{~d}$ and $\mathrm{Mal} \mathrm{d} 3$ in a group of Italian apple-allergic patients. Int J Food Sci Technol 2010, 45:1517-1523.

25. Paris R, Pagliarani G, Tartarini S, Sansavini S, Gessler C, van de Weg E: Allergen expression in control and transgenic apple plants. Acta Hort (ISHS) 2012, 929:135-142.

26. Chen L, Zhang S, Illa E, Song L, Wu S, Howad W, Arús P, van de Weg E, Chen K, Gao Z: Genomic characterization of putative allergen genes in peach/almond and their synteny with apple. BMC Genomics 2008, 9:543.

27. Holm J, Ferreras M, Ipsen H, Würtzen PA, Gajhede M, Larsen JN, Lund K, Spangfort MD: Epitope grafting, re-creating a conformational Bet v 1 antibody epitope on the surface of the homologous apple allergen Mal d 1. J Biol Chem 2011, 286:17569-17578.

28. Ma Y, Gadermaier G, Bohle B, Bolhaar S, Knulst A, Marko- vic-Housley Z, Breiteneder H, Briza P, Hoffmann-Sommergruber K, Ferreira F: Mutational analysis of amino acid positions crucial for lgE-binding epitopes of the major apple (Malus domestica) allergen, Mal d 1. Int Arch Allergy Immunol 2006, 139:53-62.

29. Ferreira F, Wallner M, Thalhamer J: Amino acid positions involved in the formation of IgE-binding epitopes of Api g 1 and Mal d 1 allergens. J Allergy Clin Immunol 2000, 105:S137.

30. Wagner S, Radauer C, Bublin M, Hoffmann-Sommergruber K, Kopp T, Greisenegger EK, Vogel L, Vieths S, Scheiner O, Breiteneder H: Naturally occurring hypoallergenic Bet $v 1$ isoforms fail to induce lgE responses in individuals with birch pollen allergy. J Allergy Clin Immunol 2008, 121:246-252.

31. Schenk MF, Cordewener JH, America AH, Van't Westende WP, Smulders MJ, Gilissen LJ: Characterization of PR-10 genes from eight Betula species and detection of Bet $v 1$ isoforms in birch pollen. BMC Plant Biol 2009, 9:24.

32. Fernández-Rivas $M$, Cuevas $M$ : Peels of rosaceae fruits have a higher allergenicity than pulps. Clin Exp Allergy 1999, 29:1239-1247.

33. Gilissen LJ, Bolhaar ST, Matos Cl, Rouwendal GJ, Boone MJ, Krens FA, Zuidmeer L, Van Leeuwen A, Akkerdaas J, Hoffmann-Sommergruber K, Knulst AC, Bosch D, Van de Weg WE, Van Ree R: Silencing the major apple allergen Mal d 1 by using the RNA interference approach. J Allergy Clin Immunol 2005, 115:364-369.

34. Krath B, Eriksen FD, Pedersen BH, Gilissen LJ, Van de Weg WE, Dragsted LO: Development of hypo-allergenic apples: silencing of the major allergen Mal d 1 gene in "Elstar" apple and the effect of grafting. $J$ Hortic Sci Biotech 2009, 84:52-57.

35. Baerenfaller K, Grossmann J, Grobei MA, Hull R, Hirsch-Hoffmann M, Yalovsky S, Zimmermann P, Grossniklaus U, Gruissem W, Baginsky S: Genome-scale proteomics reveals Arabidopsis thaliana gene models and proteome dynamics. Science 2008, 320:938-941.

36. Mauro M, Russello M, Incorvaia C, Gazzola G, Frati F, Moingeon P, Passalacqua G: Birch-apple syndrome treated with birch pollen immunotherapy. Int Arch Allergy Immunol 2011, 156:416-422.

37. Nucera E, Aruanno A, Lombardo C, Patriarca G, Schiavino D: Apple desensitization in two patients with PR-10 proteins allergy. Allergy 2010, 65:1060-1061.

38. Ukaji N, Kuwabara C, Takezawa D, Arakawa K, Fujikawa S: Accumulation of pathogenesis-related (PR) 10/Bet v 1 protein homologues in mulberry (Morus bombycis Koidz.) tree during winter. Plant Cell Environ 2004, 27:1112-1121.

39. Liu JJ, Ekramoddoullah Abul KM: The family 10 of plant pathogenesisrelated proteins: their structure, regulation, and function in response to biotic and abiotic stresses. Physiol Mol Plant P 2006, 68:3-13.

40. Chevalier M, Parisi L, Gueye B, Campion C, Simoneau P, Poupard P: Specific activation of PR-10 pathogenesis-related genes in apple by an incompatible race of Venturia inaequalis. Biol Plant 2008, 52:718-722.

41. van Loon LC, Rep M, Pieterse CM: Significance of inducible defense-related proteins in infected plants. Annu Rev Phytopathol 2006, 44:135-162.

42. Botton A, Lezzer P, Dorigoni A, Ruperti B, Ramina A: Environmental factors affecting the expression of apple (Malus $\times$ domestica $L$. Borkh) allergenencoding genes. J Hortic Sci Biotech 2009, ISAFRUIT Special Issue:182-187. 
43. Velasco R, Zharkikh A, Troggio M, Salvi A, Pindo M, Cestaro A, Fontana P, Baldi P, Costa F, Goremykin V, Malnoy M, Komjanc M, Micheletti D, Magnago P, Coppola G, Moretto M, Zini E, Dal Ri A, Si-Ammour A, Castelletti S, Stefani E, Durel CE, Lasserre P, Lespinasse Y, Dhingra A, Gardiner S, Chagne D, Mraz A, Stormo K, Tao Q, et al: The genome of the domesticated apple (Malus $\times$ domestica Borkh). Nat Genet 2010, 42:833-839.

44. Altschul SF, Gish W, Miller W, Myers EW, Lipman DJ: Basic local alignment search tool. J Mol Biol 1990, 215:403-410.

45. Wageningen Bioinformatics Webportal: http://www.bioinformatics.nl/cgibin/primer3plus/primer3plus.cgi.

46. Kootstra HS, Vlieg-Boerstra BJ, Dubois AEJ: Assessment of the reduced properties of the Santana apple. Ann Allergy Asthma Immunol 2007, 99:522-525.

47. Lee C, Kim J, Shin SC, Hwang S: Absolute and relative QPCR quantification of plasmid copy number in Escherichia coli. J Biotechnol 2006, 123:273-280

48. Paris R, Cova V, Pagliarani G, Tartarini S, Komjanc M, Sansavini S: Expression profiling in HcrVf2-transformed apple plants in response to Venturia inaequalis. Tree Genet Genomes 2009, 5:81-91.

doi:10.1186/1471-2229-13-51

Cite this article as: Pagliarani et al:: A qRT-PCR assay for the expression of all Mal $d 1$ isoallergen genes. BMC Plant Biology 2013 13:51.

\section{Submit your next manuscript to BioMed Central and take full advantage of:}

- Convenient online submission

- Thorough peer review

- No space constraints or color figure charges

- Immediate publication on acceptance

- Inclusion in PubMed, CAS, Scopus and Google Scholar

- Research which is freely available for redistribution 